ment appears long after physiological mechanisms begin to operate. The synthesis of needed enzymes and the oxidation of carbon provide the energy and intermediates that are necessary for germ tube formation.

\section{David GotTlieb}

P. G. Caltrider

Department of Plant Pathology, University of Tllinois,

\section{Urbana.}

1 Dawkins, M. S. R., Proc. Roy. Soc., B, 150, 284 (1959).

2 Oliver, I. T., Ballard, F. J., Shield, J., and Bently, P. J., Developmental Biol., 4, 108 (1962)

3 Goddard, D. R., Cold Spring Harbor Symp. Quant. Biol., 7, 362 (1939).

1 Sussman, A. S., Distler, J. R., and Krakow, J. S., Plant Physiol., 31, 126 (1956).

${ }^{5}$ Newburgh, R. W., and Cheldelin, V. H., J. Bact., 76, 308 (1958).

- Colowick, S. P., and Kaplan, N. D., Methods in Enzymology, 1-5 (Academic

Press, New York, 1955-62).

\section{Effect of Pseudomonas tabaci on the Metabolism of Starch in Tobacco Leaves}

IN the host tissues infected by various plant pathogens, including viruses, bacteria and fungi, as a rule starch accumulates around the infection area1-3. By contrast, the toxin-induced chlorotic halo formed in White Burley tobacco leaves infected by Pseudomonas tabaci (Wolf and Foster) Stevens fails to show any starch reaction (Fig. 1). The low starch content of the affected area was also shown by quantitative chemical determination ${ }^{4}$ (Table 1 ). The assays were made 7 days after needle inoculation.

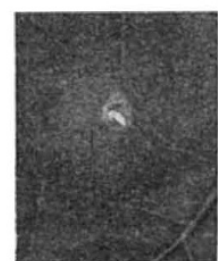

$\boldsymbol{A}$

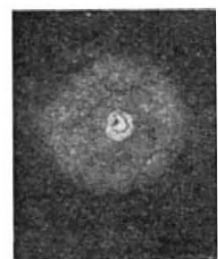

$B$
Fig. 1. Parts of a tobacco leaf after needle-inoculation with Pseudomonas tabaci. $A$, Untreated; $B$, stained with iodine

The decrease in starch content could also be induced by the injection of bacteria-free culture filtrate (Table 1). Czapek-Dox nutrient medium incubated with Ps. tabaci for $48 \mathrm{~h}$ was used. Treatments were earried out on intact plants by injecting one half of the leaves with the culture filtrate and the other with Czapek-Dox nutrient as control. Measurements were made 3 days after injection.

Table 1. EFfect of Pseudomonas tabaci on THE STARCH CONTENT AND PHOSYHORYLASE ACTIVITY OF TOBACOO LEAVES Phosphorylase activity*

\begin{tabular}{|c|c|c|c|}
\hline \multirow[b]{2}{*}{$\begin{array}{l}\text { Treatment of } \\
\text { leaves }\end{array}$} & \multirow[b]{2}{*}{$\begin{array}{l}\text { Starch content* } \\
\text { (mg/g fresh } \\
\text { weight) }\end{array}$} & \multicolumn{2}{|c|}{100} \\
\hline & & $\begin{array}{c}\text { Synthesized amylose } \\
\text { (mg/g fresh } \\
\text { weight/1 h) }\end{array}$ & $\begin{array}{l}\mathrm{PO}_{4}^{8-} \text { liberated } \\
\text { (mg/g fresh } \\
\text { weight/1 h) }\end{array}$ \\
\hline $\begin{array}{l}\text { Control } † \\
\text { Needle inoculated } \\
\text { Control } f\end{array}$ & $\begin{array}{l}2 \cdot 6 \\
1 \cdot 5 \\
5 \cdot 2\end{array}$ & $\begin{array}{l}4 \cdot 5 \\
1 \cdot 2 \\
4 \cdot 4\end{array}$ & $\begin{array}{l}1 \cdot 8 \\
0 \cdot 6 \\
1 \cdot 6\end{array}$ \\
\hline $\begin{array}{l}\text { Injected with } \\
\text { culture filtrate }\end{array}$ & $2 \cdot 3$ & $2 \cdot 3$ & 0.9 \\
\hline
\end{tabular}

To elucidate the possible mechanism responsible for decrease in starch content the activity of the two major enzyme systems involved in starch metabolism was measured. A negligible and equal amylase activity was found in the extracts from control and culture filtrate treated leaves. The activity of phosphorylase, however, exhibited striking differences. The extent of amylose synthesis from glucose-1-phosphate was measured as follows: $500 \mathrm{mg}$ tissue was extracted in the cold in $2.5 \mathrm{ml}$. acetate buffer $p H \mathbf{H} \cdot 0$. The reaction mixture contained
$1 \mathrm{ml}$. crude extract (without centrifugation), $10^{-2} \mathrm{M}$ sodium fluoride, $0.2 \mathrm{ml}$. 1 per cent dextrin as primer, and $1.7 \times 10^{-2} \mathrm{M}$ glucose-1-phosphate in $2.3 \mathrm{ml}$. final volume. After incubation at $30^{\circ} \mathrm{C}$ for $30 \mathrm{~min}$ the reaction was stopped by adding equal amounts of 10 per cent trichloroacetic acid (controls were treated with trichloroacetic acid at zero time). The starch (amylose) content was determined colorimetrically in centrifuged samples by adding $0.2 \mathrm{ml}$. of an iodine solution containing $60 \mathrm{mg}$ iodine $/ 100 \mathrm{ml}$. A standard curve was prepared from soluble starch. Alternatively the orthophosphate set free during starch synthesis was measured ${ }^{5}$.

As shown in Table 1 phosphorylase activity, as compared with the controls, was markedly less both in the halo areas of the infected leaves and in the tissues treated with culture filtrates.

The Ps. tabaci strain used in these experiments does not hydrolyse starch. The culture filtrate added to phosphorylase-containing plant extracts in vitro did not diminish the activity of phosphorylase. Therefore, it can be stated that the decrease in phosphorylase activity is due to an indirect effect of $P s$. tabaci on the metabolism of the host. This effect is specific because the activity of some other enzymes, for example, glucose-6-phosphate dehydrogenase, increases in the tissues surrounding the infection area. The parallelism between the decrease in starch content and inhibition of phosphorylase activity suggests a causal relationship.

\section{LOVREKovicï}

Z. KLEMENT

G. L. Farkas

Research Institute for Plant Protection, Budapest.

${ }^{1}$ Smith, K. M., Recent Advances in the Study of Plant Viruses (J. and A. Churchill, 'Ltd., London, 1951).

${ }^{2}$ Goto, K., and Fukatsu, R., Bull. Div. Plant Breeding and Cultiv., 2, 41 (Tokai-Kinki Nat. Agric. Exp. Stat., 1955)

a Allen, P. J., Ann. Rev. Plant Physiol., 5, 225 (1954).

McCready, R. M., Guggolz, J., Silviera, V., and Owens, H. S., Anal. Chem., 22, $1156(1950)$.

${ }^{5}$ Whelan, W. J., in Methods in Enzymology, 1, 192 (Academic Press, Inc., New York, 1955).

\section{Optimum Leaf Area Index in the Potato Crop}

In his review of the effect of competition for light on crop growth Donald ${ }^{1}$ notes the existence of but two published accounts presenting evidence to support the generally adopted conception of an 'optimum leaf area index' as the ratio of leaf area to ground covered at which the balance of photosynthesis over respiration is at a maximum value. For kale crops in southern England the figure lies between 3 and $\mathbf{5 . 4}$ (ref. 2). In Australia, subterranean clover was found to reach its highest net assimilation rate when the leaf area index lay between 4 and 5 (ref. 3). More recently, Stern and Donald 4 have shown that the optimum leaf area index for clover in Australia varies with the amount of light present, particularly the amount which penetrates to the lower leaves, rising from 3.5 at a radiation-level of $50 \mathrm{~g} \mathrm{cal} / \mathrm{cm}^{2} /$ day to a nearly constant 5 above $150 \mathrm{~g} / \mathrm{cal} / \mathrm{cm}^{2} /$ day. Donald ${ }^{1}$ calls for more evidence for other crops and different regions.

In an experiment on the effect of applying four levels of a 12 per cent $\mathrm{N}: 12$ per cent $\mathrm{P}_{2} \mathrm{O}_{5}$ : 18 per cent $\mathrm{K}_{2} \mathrm{O}$ fertilizer to a crop of Majestic potatoes at Boghall, Midlothian, in 1961, measurements were made of leaf area and the dry matter of leaves, stems, roots and tubers at four dates each approximately three weeks apart. The plants which received 2.5 and 5 cwt. per acre rates of fertilizer (Fig. 1) show a steady rise in leaf area index to 4.4 and 5.3 respectively at the third sampling date, declining thereafter to 3.9 and 4.9 . The plants given the $7 \cdot 5$ and 10 cwt. per acre treatments rose swiftly through the level of leaf area index 5 to reach maxima of $7 \cdot 0$ and $8 \cdot 3$, after. wards declining to $5 \cdot 5$. 